\title{
J. F. Powers \& Betty Wahl: Irish Americans \& Returning Yanks
}

\author{
John L. Murphy \\ DeVry University, Long Beach, CA, USA
}

Copyright (c) 2013 by John L. Murphy. This text may be archived and redistributed both in electronic form and in hard copy, provided that the author and journal are properly cited and no fee is charged for access.

\begin{abstract}
The limited critical attention given J.F. Powers (1917-99) has concentrated on his engagement with Catholicism. Powers also applies Irish American motifs to his fiction. This article analyzes the depiction that Powers and his wife Betty Wahl (1924-88), who left postwar America to live on and off in Ireland, made of the Irish in both their homeland and in America. Powers only once directly addressed his own experience as a sporadic Irish resident, in the final story, "Tinkers," anthologized in his third and last collection in 1975. Wahl's writing career proved limited. Her only novel, Rafferty \& Co. (1969), semi-fictionalizes the Powers family's decision to move to Ireland, for a series of extended stays in the 1950s and early 1960s. This article examines these writers' dramatization of postwar Ireland as expatriate Americans. Powers' story and Wahl's novel depict the stresses of living in suburbs south of Dublin while struggling to sustain a countercultural yet conservative idealism. That combination drove the family away from the Midwest, in both fiction and fact, to settle in an economically destitute and patriotically insecure Ireland.
\end{abstract}

Keywords. American literature, satire, emigration, expatriates, Irish Americans, American Catholicism, J.F. Powers, Betty Wahl.

Resumen. La escasa atención crítica que J.F. Powers (1917-99) ha recibido se ha centrado en su relación con el Catolicismo. No obstante, Powers trató también motivos irlandeses-americanos en su ficción. Este artículo analiza el retrato que Powers y su esposa Betty Wahl (1924-88), que dejaron la América de la postguerra para vivir esporádicamente en Irlanda, hicieron de los irlandeses en su tierra y en América. Powers trató su propia experiencia de residente ocasional en Irlanda en una única ocasión: el relato "Tinkers", recogido en su tercera y última colección, publicada en 1975. La carrera literaria de Wahl fue reducida: su única novela, Rafferty \& Co. (1969), es una semi-novelización de la decisión de la familia Powers de instalarse en Irlanda en una serie de estancias prolongadas a lo largo de la década de los 50 y principios de los 60. Este artículo examina la dramatización que, en su condición de expatriados americanos, estos escritores hacen de la Irlanda de postguerra. El relato de Powers y la novela de Wahl describen las tensiones resultantes de vivir en barrios residenciales del sur de Dublín e intentar mantener un idealismo contracultural y al mismo tiempo conservador. Dicha combinación alejó a la familia del Medio-oeste, tanto en la ficción como en la realidad, para establecerse en una Irlanda económicamente indigente y patrióticamente insegura.

Palabras clave. Literatura Americana, sátira, Catolicismo americano, J.F. Powers, Betty Wahl.

Born in 1917 in Jacksonville, Illinois, James Farl Powers wrote as J.F. Powers and went by Jim. Of Irish and German parentage, he studied emigración, expatriados, Irlandeses-americanos,

at Northwestern University; he worked in sales, as a chauffeur, in a bookstore, and as an editor. He began to write. Powers examined

ISSN 1699-311X 
Midwestern Catholicism. He invented, for most of the thirty stories published over thirty years in three slim collections, a couple of rural dioceses in his adopted Minnesota, where German and Eastern European descendants contended with Irish Americans, nearly all Catholic.

A Catholic Worker who was jailed as a pacifist during the Second World War, Powers despised the military-industrial complex. He sought an antidote to the "edifice complex" of enormous parish plants, oversized rectories, impoverished convents, and overcrowded parochial schools with thermometers to show the rise of fund-raising drives. While his scrutiny of Catholic mores has gained critical attention, his incorporation of Irish American contexts - and his four "removals" with his wife and family back and forth from Ireland has not earned equal attention. This article will investigate Powers' use of Irish themes in his short stories and his novels.

James Joyce, in "Gas From a Burner," sneered: "O Ireland, my first and only love,/ Where Christ and Caesar are hand in glove." Powers followed both Joyce's satirical bent and his detached presentation of clerical connivance. With deadpan tone and poignant stoicism, Powers dramatizes clerics and laity (mostly prior to Vatican II) who try to sustain Catholic separation from Protestant culture. They attempt to resist assimilation, but capitalism tempts them too.

Frank O'Connor numbered Powers "among the greatest of living storytellers" (1956: 22). In his introduction to the collected stories, Denis Donoghue contrasts Powers with his friend Seán O'Faolain, whom Donoghue notes wrote two thousand words a day no matter what his mood. Powers might spend the morning debating between a colon or semicolon. Donoghue explains that as a "writer's writer", Powers "was an artist too good to gratify the most casual reader, but he was also a reader's writer, if we assume a reader who thinks of fiction as intelligent art rather than low entertainment. Such writers tend not to be abundant" (2000: vii).

His best stories probe gently but relentlessly how moral dilemmas unfold within a superficially trivial job or mundane career, often one in a rectory or chancery. As he noted to a creative writing student: "If a human being buys an insurance policy, that's not much of a story. But when a priest buys an insurance policy, there's something going on that needs to be said and I want to say it" (Laurance 2001).

The struggle between what he called Church and Dreck entangles his clerical figures. This tension, through what a salesman hawks as "The Plan" to Father Joe Burner, opens the title story in his first story collection, The Prince of Darkness and Other Stories (1947). The priest is nicknamed "The Prince of Darkness", and not only for the darkroom he haunts while developing snapshots in the rectory. Evelyn Waugh blurbed on its cover: "a magnificent study of sloth ... . which brought an alarming whiff of brimstone to the nostrils of at least one reader". The Presence of Grace (1956) \& Look How the Fish Live (1975) also alternate uneven depictions of laity with more nuanced investigations of the clergy. His novels Morte d'Urban (1963) and Wheat That Springeth Green (1988) incorporate and elaborate his earlier clerical stories. They delineate midcentury Middle American parochialism.

\section{"Prince of Darkness" and Irish Americans}

Powers addresses Irish themes indirectly and sporadically in his earlier clerical fiction. For instance, in "Prince of Darkness" during Fr. Burner's "first church supper", he listens as a young girl is paraded before the Dean and Monsignor to show off her diligent preparations for Confirmation. Monsignor asks her to list the seven deadly sins. She stumbles halfway. The priest recalls the "child's mother, one of those tough Irish females built like a robin, worried to death, lips silently forming the other sins for her daughter" (1947: 247-48).

As the story continues, Fr. Burner's old mentor, Fr. Desmond, succumbs again to drink. His protégé reflects: "It was funny, if a little tiresome, the way the Irish could exaggerate a situation. They all had access to the same two or three emotions. They all played the same battered barrel organ handed down through generations. Dying, fighting, talking, drinking, praying ... . wakes. The fates were decimated and hamstrung among them. They loved monotony" (1947: 257). In the final scene, as the priest tries to avoid the fate of his old friend, he is summoned to the chancery. The Archbishop teases Fr. Burner about his first name, Ernest. The priest admits that a couple of men so named were canonized, but they were 
left out of Butler's Lives of the Saints. The Archbishop responds: "If Butler had been Irish, as the name has come to indicate, I'd say that's an Irishman for you, Father. He does not forget to include a power of Irish saints" (1947: 275). This last turn of an Irish locution may also show the author's punning entry of later arrivals to Ireland alongside the ranks of the canonized Celts, as Powers shared great pride in his own Hiberno-Norman ancestry.

Sensitive to every such nuance, desperate for promotion to a pastor, haunted by Fr. Desmond's own hospitalization, Fr. Burner ponders as if a diplomat every utterance of his superior. The Joycean method of indirect first person discourse serves as Powers' own chosen narrative voice. In it, his protagonist reflects silently: "The Archbishop was Irish himself. Father Burner begged to differ with him, believing there was a wrong set up for him to right" (1947: 275). Powers' use of the rhetorical shift, the particular standing for the universal, the conversational aside representing the universal truth, conveys in the manner of Joyce a continued concern with the battle between the body and the soul, the vowed life of renunciation and the sensual embrace of the world. Fr. Burner faces his final test, to become a saint worthy of entry into the martyrology. The Archbishop, beneath his worldly veneer and small talk, knows this better than Fr. Burner.

The assistant pastor, ready for his parish, answers smartly. "I am not Irish myself, but some of my best friends are". The Archbishop answers. "Tut tut. Father. Such tolerance will be the death of you". He signs a note, places it in an envelope, and turns to his shelf. Opening another venerable hagiographical reference, the Archbishop hurriedly checks it. "No Ernests in Baring-Gould either. It looks as if you have a clear field" (1947: 276). The conversation concludes, and Fr. Burner leaves and opens the letter. It assigns him to yet another curacy, under the direction of one "Reverend Michael Furlong" (1947: 277). Again, an Irish pastor will supervise this German assistant. The Archbishop's message with a cutting Gospel allusion ends this missive and thus this title story. "I trust that in your new appointment you will not find peace but a sword".

The collection concludes with a subtle but telling incorporation of Irish leadership over restive ethnic clergy, and the resentment felt by
Fr. Burner throughout his stint at St. Patrick's will, as the two entries in the next collection of stories The Presence of Grace reveal, continue, if in less ethnically defined terms.

His novels diminish references to Irish identity. Morte d'Urban features its protagonist among other priests and laity who possess Irish surnames, but these markers remain as mundane as Croatian or German monikers. Wheat That Springeth Green barely nods to ethnic differences.

Although his story "The Prince of Darkness" has been anthologized by David Pierce in his magisterial Irish Writing in the Twentieth Century: A Reader and his story "Bill" which inspired the novel Wheat That Springeth Green - by Daniel Casey and Robert Rhodes in their Modern Irish-American Fiction: A Reader, Powers only once directly addressed his own experience as a sporadic Irish resident.

\section{Powers and Wahl}

Jim and his wife Betty Wahl (1924-1988) left postwar America to live on and off in Ireland. She published stories in The New Yorker. Her output remained sparse; she raised their five children on the little her husband eked from teaching, and less from his writing. Her only novel, Rafferty \& Co. (1969, expanded from a 1964 story in the Kenyon Review, "A Shorter History of the Irish People"), semi-fictionalizes the Powers family's decision to move, for three (out of what would total over their lifetime four) extended residences in the 1950s and 1960s, to Greystones twice and Dalkey once.

Powers reasoned he could live more cheaply in Ireland than he could by creative writing instruction, allowing for his own meticulously slow pace of composition. Wahl's story and novel depict an American family entering a still-impoverished Ireland, prior to but in key plot details foreshadowing the Troubles. The novel addresses the stagnation of the native weaving trade, as well as urban fecklessness, American support for "The Cause", and Irish American expectations contrasted with the capital city's moribund mentality and pinched reality. The oddity of the Powers' own decision to depart St. Cloud, Minnesota, for south of Dublin despite the family's straitened finances stretches tension. Reflecting this same expatriate choice, Powers wrote but one story — "Tinkers" concludes his final 1975 collection - situated in Ireland. 
While Powers' works have been restored to print, Wahl has suffered critical neglect. Both "Tinkers" and Rafferty explore economic stagnation and satirize domestic itinerancy as encountered by overeducated and underpaid Returning Yanks. This trope in turn satirizes the upwardly mobile American Irish who romanticize the Republic. Powers and Wahl create a postwar Irish setting conveyed intimately but with deliberately blurred context within Anglo-American cultural changes of the 1950s and 1960s. These two tales, despite their later publication dates, remain wryly ambiguous. They choose reticence as often as candor. They occur when jet flight began to change immigration patterns and stimulate mass tourism. Rejecting this, both fictions evoke a fading era of travel from America to Ireland by ship.

"Tinkers", the only story published which draws upon Powers' Irish residency, ends his last collection. The story's origins predate its 1975 inclusion in Look How the Fish Live, undated in its acknowledgements but attributed to American Review. As this influential smallpress magazine changed its name to this in 1973, that appears to be the correct year; the copyrights of the ten stories gathered in Look span 1957 to 1973. This interval attests to Powers' deliberate pace of composition. His stoicism provided not only the impetus to seek out Ireland as a more affordable place to live given the author's exacting method of production, but the means for the teasing satire within "Tinkers".

While his previous collections ended with the title story, for the third collection, the title story opens the collection while "Tinkers" closes it. This decision by Powers underlines its importance. Despite his 1963 National Book Award for Morte d'Urban, Powers remains best known for his shorter, and clerical, fiction. The final story Powers placed in print (if fourteen years before his death) serves as a personal coda to his own peripatetic lifestyle and his Irish heritage. This placement hints, with typically understated fashion, at its significance.

Neither the reticent Jim, whom his friend Jon Hassler summed up as "a saint with a bad temper", nor Betty appear to have confessed to confidants why the Powers clan chose to move again and again to Ireland. Their daughter, Katharine Anne Powers, has published a few excerpts from J.F's correspondence from the first three series of Irish residences in the early 1960s. When she publishes the complete edition of his letters, more insights may emerge. In the letters printed so far, Jim continues his familiar if terse grousing about Cold War capitalism. Given a couple of homebody writers preferring to keep their distance from suburban America and its brash consumerism, any hints as to their Irish predilections must be teased out of their fiction. "Tinkers" edges towards expatriate unease that his wife's Ireland novel develops and deepens.

\section{"Tinkers"}

The characters in "Tinkers" deliberately mimic those in a bedtime story. Mama and Daddy bring five unnamed children over by ship to Cobh from New York City. Preceding this, a train from Chicago conveyed the family; a train from Cork to Dún Laoghaire and then to Ballydoo follows. (Denis Donoghue comments that this suburban Co. Dublin locale is a "standin for Greystones" [2000: viii].) Eight days of travel by these genteel conveyances date the story, removing it immediately from the transatlantic era of quick flights to Shannon or Dublin. Despite the story's early-to-mid-1960s feel, Powers provides no references to specifics beyond the familiarity of Bewley's, Aer Lingus, the B.B.C., or the Electricity Supply Board. Powers suspends the narrative outside of a particular year; this vague chronology also permeates Rafferty \& Co.

The narrator, filtering Daddy's own point-ofview in the Joycean mode of indirect voice often employed by Powers, relates the family's first encounter on their road to their new home in Ballydoo. Their taxi passes two tinkers arguing about selling a horse. This scares the older of the two youngest sons, who holds on his lap Beebee, a toy teddy cast as a millionaire in both the boy's imagination and his tiresome stories recounting a bear able to travel first class and afford the luxuries far beyond the reach of these seven penny-pinching Americans. The strain tugs at the whole story Powers tells. Resenting Beebee's extravagance, as ventriloquized through his son's flamboyant boasts of the bear's champagne tastes, Daddy 
vows to live cheaply. They will stay in a hotel closed for the off-season. Although named Westward Ho, it faces east against the wintry Irish Sea. Run by a British couple, the Major and Mrs. Maroon, these names again illustrate the off-hand tone adapted by Powers towards this thinly-fictionalized tale of living in Ireland on as close to five dollars a day as possible.

This is the family's fourth stay. In real life, the Powers would live four times there, a year or two off and on from 1951 to1965, followed by a longer duration 1966 to $1975 .{ }^{1}$ Some of the Powers children stayed in Ireland after their parents returned for good to Minnesota. In Greystones and Dalkey, Mr. and Mrs. Powers tried to save money so he could quit teaching and write. Daddy shares this precarious profession. "He kept the family in combs he found in the street and washed - how many fathers, not professional scavengers - did that? He had paid for three deck chairs on the ship coming over. In Ireland, he had only smoked pensioners' plug. In short, he was probably America's thriftiest living author"(1975: 176).This reduction to the life of an educated but wandering band of scholars has not pleased any of Daddy's clan. Their venerable home in a college town was demolished for a parking lot and dormitories; their previous place in the woods had succumbed to a highway's service road. These details resonate with the suburban father's plight in the title story of Look How the Fish Live.

Both stories, bookending this collection, betray frustration at bureaucrats. The tales oppose the relentless expansion of an infrastructure that obliterates the local landmark, the welcoming lawn, or the sylvan retreat. These stories, rare for Powers as derived from his own life, express the reactions of characters - neither as parishioners nor as priests - to the postwar American capitalism that links D.D.T. with Civil Defense, campus expansion with bulldozing, and consumerism with patriotism. Jingoism spawns bitterness and helplessness. This apprehension against market forces unites the author - the college-town

1. One daughter, Aosdána member and printmaker Mary Farl Powers, inspired her lover Paul Muldoon's "Incantata" by her fatalistic decision not to treat the cancer which killed her in 1992.
Minnesota homeowner who flinches at the destruction caused by Mother Nature, himself, and his neighbors - with Daddy.

In the battle of "usurpers and usurpees", Mama and Daddy cut their losses (1975: 177).They decamp to Ireland yet again. Daddy wonders if he can pitch a box-office hit. But, the possibilities inherent in foreign tourists hiring a horse-drawn caravan which leads to romance between the visitors and tinker lasses discourage him. How can his countrymen, he wonders, relate to this topic? "He knew nothing about tinkers or Germans or, they might be, French, and if he got them acting and talking right, would they, particularly the tinkers, be intelligible to an American audience? Would this audience — as it must — immediately grasp what the Germans, French, or, they might be, Japanese would not; namely, that the tinkers were not proper campers like themselves?" (1977: 178). How to distinguish "tinkers" from "proper campers" for this prospective audience back home generates plot complications that puzzle Daddy in "Tinkers".

Daddy's own respectable family has been forced into following his own decision for the fourth time to move from America to Ireland. This shames Daddy. He rationalizes that the undernourished Irish economy will enable these seven Americans to survive off their savings long enough for untenured, renting, and impecunious Daddy to create, finally, a work that will pay the bills. He suspects that he has failed as a provider and father. Beebee the bear lives the high life in his son's fantasies, while he, his siblings, and parents shuffle from one abode to another, a few months here and there. Unsettled, they touch land across an ocean, washed up at Ireland's eastern edge.

Daddy's hesitation produces attenuated prose. Full of commas and pauses, the writer's inner monologue reveals his lack of commitment. He cannot manufacture a dishonest product. But, his integrity collides with his confusion. As a Yank, he confronts the tinker stereotype. The figure stands for vagabond whimsy and shouted argument which scares his son. The tinkers' presence, the dramatic potential inherent in the Other and a hackneyed Romeo and Juliet set-up, cannot be sustained. Daddy tries to conjure up a stage success. "There would be singing, dancing, drinking, and fighting around the campfire, a 
nice clash of life styles (these, in the end, would be exchanged!) with plenty of love interest along the way - German boy, tinker girl, or vice versa, maybe several of each for more love interest" (1975: 178). But, theatrical restrictions drag him down. The truth behind caricatures cannot be plumbed in a couple of hours of patter and blarney.

Daddy cannot leap the divide that separates his American idiom from his Irish surroundings. "He was afraid he'd have to do the whole damn thing in basic American first, then do a vivid translation, thoughts of which, since he was still in several minds as to the campers' nationality (Wunderbar! C'est magnifique! Banzai!) turned his stomach slightly. He had once read that nobody ever wrote a best seller, however bad, without believing in it, but he doubted this, and even if it was true, he doubted that it was true of a smash-hit play, however bad" (1975: 178-79).

Filled with clichés but determined to remain honest, Daddy's plight represents Powers' moral commitment. The Ugly American attempting to exploit local color to deepen his pockets, the vocation of the sincere writer within show business, and the inability to reconcile sincerity with sales enter, for Powers, into the mental battle within an author's creative process. For the first time, Powers shows readers an author at work. The diagnosis and treatment of writer's block - a condition certainly familiar to Powers given his rate of five books, one per decade published over half a century - may not be fresh subject matter, but for Powers, he invigorates this topic by paralleling Daddy's restlessness with the tinkers themselves.

Near the start of winter, a month left on their lease, Mama and Daddy "were talking more about their problem". They look at houses; "one just not what they'd come to Ireland to live in (a thirties-period 'villa' of poured concrete spattered with gravel - the agent had called it 'pebbledash'), and one very nice place, 'small Georgian,' with a saint's well on the grounds, but unfurnished and rather remote and, it then came out, not for rent, the agent having presumed that they, as Americans, might buy it" (1975: 180-181). Comforted by news of Midwestern floods and snowdrifts, fearing that any house there could have a highway "rerouted through his living room",
Daddy allows himself "to feel sorry for their home owning friends in America" (1975: 181). He seeks "the consolations of vagrancy", of not having to invest in home repairs that may outlast one's domestic residency. Daddy fails to sway Mama to admit the superiority of "mobile families". Given he cannot recall any pertinent hints from the "Women's Hour" B.B.C. show, Mama remains unconvinced by Daddy's attempted appropriation of house husbandry.

However, tenants return to the hotel for Christmas, so the family must shift into smaller quarters. Feeling hemmed in, Daddy delays working on the tinker play while he reads The Irish Times. Bureaucrats await publication, he finds, of a "report prepared by the 'Government Commission on Itineracy.' Shouldn't that be Itinerancy?" he wonders (1975: 183). Powers sends up the Irish mistake in nomenclature, echoing the blunders of American highway builders and dormitory erecters who have destroyed his earlier homes, in his own Minnesota campus-adjacent life and in the title story of Look How the Fish Live.

Recounting their first uprooting from the home they loved, the narrator tells us: "Fifteen years earlier, Mama and Daddy had begun their career as tenants and travelers, when they'd surrendered their house in the woods, the first and last place they'd owned, to the faceless men of the highway department" (1975: 17677). Their second house, the oldest one in town, was paved over for a college dorm and parking lot. Their third home was rented, until the owners "planned to turn it into a barracks with bunk beds" for more students (1975: 176). Daddy cannot escape a cycle of failing to settle down.

Powers' daughter verifies her family's frequent uprooting: "My parents had rented half the 'hotel,' for the off-season, with the understanding that we would have sole possession during our stay and that JFP could use a room on the empty side for a place to write. The owners came back and set up residence. This experience eventually resulted in the short story "Tinkers"'. Katharine Anne Powers verifies that the "escape to a good house up the road" also found its way into her father's tale (2002: 106-107).

Daddy reads the account of litter and begging, and the friction predicted as the report seeks to integrate itinerants into "the normal 
life of the community". Caravans in winter, he finds, camp often in the suburbs or towns, "but some caravans stay on the road all year round". He thinks: "Nothing new here, nothing for him". Until Daddy finds the clans listed. "'There are six main tinker tribes.' Oh? 'The Stokes, Joyces, MacDonaghs, Wards,' . . . now, wait a minute. . . 'and Redmonds"'. This passage exhibits Powers' tendency to suggest rather than highlight, perhaps too obliquely. Daddy reflects: "So, the odds against him were greater than he'd thought". He, evidently although unnamed, descends from these same itinerants. He inherits their wanderlust. His family must trudge along behind him as he keeps traveling, renting, house hunting, moving. This scene illustrates Powers' reluctance to call attention to his techniques of indirect reference and restrained detail. Critics have acknowledged that among Powers' considerable skills, such precision may edge towards fussiness. Jon Hassler, his colleague and fellow writer, chooses this excerpt to critique what he regards as a fault of Powers, his tendency towards "reticence, or hyper subtlety". Until Hassler heard Powers' explain this reference on a radio interview, he had missed Powers' point (2000: 105). Daddy's perusal of the six tribes when examined enumerates five. The ellipses after the fourth name allow for the insertion of Daddy's own surname.

The elision represents the ambiguity of Daddy's status. This aligns with the absence of names given any of the family in the story. All remain sons and daughters, boys and girls, Mama and Daddy. Lack of signifiers keeps the story from being tied too closely to Powers, although one suspects that his own surname (a common Traveler one) remains a contender for silent membership as the fifth tribe. Regardless, this episode draws the protagonist closer towards these travelers, mysterious Irish cousins he never before contemplated. Having returned to Ireland to be assured of his status as respectable, Daddy must confront his family's roots. His own habitual rootlessness places him closer to the tinkers, foreshadowed by the faintly menacing encounter as witnessed from the taxi that ferried them to Ballydoo.

Daddy makes amends, perhaps as research for his play, perhaps to assuage his guilt at his previous attitude towards the tinkers' presence on the roads and city streets. He had overheard them, but had not treated them with any personal attention. Suddenly, he changes. "He took the next train into Dublin, left the Irish Times on it, and gave the first tinker woman he met a coin, wanting and not wanting to know her name" (1975:183). Perhaps the abandonment of the newspaper that informed Daddy of his ancestral bonds with the tinkers stands for his rejection of the bourgeois paper of record, and his wish to leave the Anglo-Irish culture for the indigenous descendants of the roads. Yet, this tinker encounter remains brief. Daddy hesitates between disclosure and separation. He fears the knowledge that would lead to kinship. $\mathrm{He}$ realizes that his gesture, contained within that accepted by beggar and donor, stays within socially accepted bounds. These preserve the dignity and anonymity of both giver and taker as a stereotypical exchange. Anything more intimate may prove as invasive as the hackneyed dialogue and risible representations of tinker lasses and German youths in the play he's trying to write.

Buying a ship's lamp as he browses in Dublin, Daddy reflects on the generosity and fecklessness of the trusting Irish he has met while attending dramas or frequenting hotels. He lacks deeper understanding, however, and notes that the native reluctance to be tipped, to be rewarded for favors done to the customer, sums up the Irish mentality. "That was the beauty of, and the trouble with, Ireland" (1975: 185).The pressure of earning enough for his family, amidst the Irish preference given those promoting manners over money or ambition, wears Daddy down. The arrival of another lodger, knitting under the Christmas tree, hastens the family's flight that evening "out of the hotel and into a house down the road" (1975: 186). They sign a temporary lease and move in immediately, again with a cabbie's help.

Until the power can be turned on, the family sits by candlelight, and then needs more illumination. Daddy reflects on their condition. "No, he did not know where the ship's lamp's ship was (the younger boy wanted to know), probably it wasn't, and no, didn't know what he was going to do with the ship's lamp. Just liked it, just liked looking at it, he said, and, seeing that that wasn't enough, said he might put it over the front door of the house they might have in America someday". He assures them, alluding to his earlier delight at inclement 
Midwest squalls, "that these old ship's lamps were made to be out in all kinds of weather" (1975: 187). Like the tinkers, the goods Daddy now buys may have to confront the elements, uprooted on their own journey away from the shelter of an inn, rather than stay indoors on a December night.

The relocated family waits for the E.S.B. The ship's lamp lights the shadows as they occupy the latest stage on their itinerary. The "younger boy" asks: "Will we get to keep it, Daddy?" Daddy thinks he means the lamp, but the boy means the house, back in America, where he hopes they can live, finally, for good. "Yes, of course, when we get it". Daddy's reply fails to please the child, so he gets up and retrieves a paperback left in his coat and borrowed from the meager offerings in the Maroon's hotel: "The Market: The Buying and Selling of Shares" (1975: 188). This action brings Daddy to the door of their new dwelling. At that moment, a garda checks in on them, noticing the lights on in what was an unoccupied building.

Is Daddy's family now suspected among the local itinerants squatting in an abandoned house? This remains unsaid. Responding to the policeman, Daddy explains how long they will stay. "Six months. Have a six-month lease. May be here longer. Probably not. It's hard to say. We never know" (1975: 188). Returning to the dimly lit parlor, Daddy finds out that the economic treatise offered Beebee's owner will not be welcome. The bear Beebee had been traded by the boy so he could spend the money playing billiards on the Maroons' coin-operated table at the hotel. Daddy buys him back from the boy's friends to which Beebee had been sold, But as he tucks the boy to sleep, "there was a gurgle in the dark that made him wonder if he had been taken". Daddy shares guilt in this transaction. He lies that the bear was a gift from his mother to get him back, and then recalls he "had been too broke to attend" her funeral (1975: 189).The father's thrifty nature and his unease at the strain that straitened finances cause for his family reverberate, into Daddy's past and, through his children, towards their uncertain future.

The story ends with Mama and Daddy listening to home news on the Armed Forces Network. Blizzards prove general all over the Midwest. The couple speculates about light fixtures; Daddy laments the different plugs needed for Irish houses and the variety of mismatched connections for the brass lamps. "The odds are three or four to one against you whenever you move", Daddy sighs (1975: 190). They reflect about the life they left behind, and the fate of their Midwestern houses. "After that they talked - he did - about their friends in America, about Joe and the highway, about Fred and the river, more about Dick and those big old trees that were probably heavy with snow and ice now, and about that big frame house that had to be painted every five years".

Powers, whose first collection had opened with "The Lord's Day", in which a pastor tears down the few remaining shade trees that protected the parish convent from summer's assault, closes his last story three decades later with an acknowledgement of the comforts of home. The house may copy a non-Hibernian model, and may be a type rejected earlier as not Irish, but for six months, at least, they have found another home. "That's one good thing about a house like this', he said. 'Pebbledash"'. Daddy learns to live in Ireland in a non-Irish house. Out of such contradictions, Powers creates his characters suspended between Ireland and America.

\section{Rafferty \& Co.}

Betty Wahl produced her only novel from this same transatlantic tension. Rafferty \& Co. carries her explanation on its back cover dust jacket. "We have moved around quite a bit, trying to get out of the path of highways, colleges, and other landgrabbers, and what with the moving and the children my output has been only half a dozen published short stories. One of these, 'A Shorter History of the Irish People', published in Kenyon Review, was the story of Rafferty, but he would not be confined to a dozen pages, and Rafferty \& Co. is a further attempt to contain him". In fact, portions of her novel also exist in New Yorker stories, but Wahl extracts the kernel in the Kenyon story of what would grow into the tough nut that Rafferty represents. Her protagonists, Pat Rafferty and his wife Alice, leave postwar America for Ireland.

The time remains as vague as does that of "Tinkers". As in Powers' story, neither Wahl's story nor novel indicate that television has entered the island, so perhaps the pre-R.T.É. decade has been deliberately (despite the 1964 Kenyon date and the 1969 Farrar, Straus \& 
Giroux printing) blurred to represent the 1950s. Late in the novel, a list of current events drifts in, the only indication of political tensions in the Cold War era: "Apartheid, Enosis, Kenya, Jordan, Panmunjom" (1969: 293).These suggest the African, Cypriot, Middle Eastern, and Korean battlefields of the Fifties rather than the diplomatic debates of the Sixties.

Wahl, sharing Powers' own preference in fiction and fact for ocean transport to ferry their fictionalized family to their new home again south of Dublin, opens her novel with their arrival by sea. Rafferty determines that he will take seven or eight days to travel from an Upper Midwest college town to his sabbatical, where he has been given grudging permission for "Research into the history of weaving down the ages". An assistant professor of history at undistinguished Oakley College, Rafferty tires of teaching general education courses to indifferent students, and he opposes the college's eager acceptance of government funds to expand its science and athletic programs. He cherishes the liberal arts, against a rising tide of ebbing standards (1969: 5).

However, he and his college president, Dr. Steichen, know that Rafferty will not spend time in the library in Dublin. Rafferty will open an Irish branch of his family's struggling weaving enterprise. His brother, Frank, provides the funds for Pat to try to hire, as promised by the Irish government, native craftsmen who will supplement their farming income on the side, at a loom. By this intervention, Rafferty hopes to leave behind a life identical to that which Daddy and Powers himself fled. This quest (as Wahl's dust jacket summation documents) demands staying one step ahead of bulldozers and developers as the family tries to find peace beyond the reach of bureaucrats, timeservers, and builders. Frank wants to modernize the plant at home; Pat dreams of providing a few Irish workers jobs that allow them to stay at home rather than take the mailboat to England.

Wahl's novel stresses the contradictions of an American academic coming to teach the Irish how to revive a moribund trade. On the ship coming into Cobh, Alice listens to an explanation of the usual situation. "Now, emigration', an Irish voice was saying, 'is the boys and girls leaving Ireland, and immigration is the same ones landing in America. It's all the one thing'. 'Yes', said Rafferty, 'but someone moving into Ireland - 'Ah, you'll find none of that'" (1969: 5). From this initial encounter on, Rafferty will be misunderstood. He cannot be bothered to correct the man's inquiry once Rafferty announces his intention to weave tweeds. The Irishman nods: "Ah, modern American methods, nylon and all that". Frank, in fact, suggests the same method for his brother's production that Frank uses in the family factory back home. But synthetics cannot be tolerated by Pat. He is a purist.

On the streets, Rafferty cannot make sense of Ireland. "This is what made a country foreign. You didn't know what anything meant. Men who looked like bums were sober workmen, and the picturesque women in plaid blankets were the ones who wanted a handout" (1969: 13). This recalls Daddy's recollections of the tinker to whom he gave the change, embarrassed and yet wistful, after his own discovery of his kinship via the article in The Irish Times. Eager to find new plaid blankets, but made from natural heather rather than manmade fibers, Rafferty too will spend an inordinate amount of time scanning the press. He places ads for weavers, but his efforts to recruit from Galway or Donegal, the craft's strongholds, meet with disapproval from the bureaucrats, who fear that the workers, once in Dublin, will never return to naGaeltachtai.

Rafferty, filtered through Wahl's wry sensibility which she shares with her husband's characters, grumbles to himself. "Considering the way they were going to depopulate the West, it was odd that his ads had not pulled in a single reply" (1969: 131). The fiction of Gaelic Ireland, propped up by grants and prevarication in the eyes of his city neighbors, shrinks before the facts of an Irish infrastructure of musical chairs, few places on the ladder, and the mailboat to England or the cousin promising a job in America. Pat pledges to change this.

His American energy demands "the necessity to get things done. Ongoing, that was what they had to be if they were to survive in this country" (1969: 50). Inevitably, Rafferty's idealism dims. Alice wonders if they will always remain "strangers among the Gaels" (1969: 41). The system proves entrenched, and as an outsider Rafferty makes no true friends. Like Daddy, he holes up with the local papers, the radio, a pipe, and broods in a drafty room.

Encountering an Irish civil service obsessed with tea breaks, endless lunches of fatty chops, 
and jugs of stout, Rafferty finds that the promises of economic assistance provided foreign investors remain empty rhetoric. The lists of weavers prove four years old, garnered from a questionnaire primarily intended to survey bacon production. Rafferty, lacking practical knowledge of the trade, nevertheless forces himself to learn. Desperate to support his family and establish a business within the two years granted him by Stiechen's leave and Frank's money, Pat scours the lonely roads of Wicklow in search of talent.

Fueled by the niceties of "ritual cups of tea" with farm families, sharing hours of conversation but no firm commitments from those who had answered that bacon survey, Rafferty cannot escape the slow pace of getting work done when he leaves Dublin for the boreens. He has been set up by the civil service as a foreign expert. But, Rafferty never has woven. He remains an outsider. "Here he was just The American, or, as he had once overheard it, The Yank" (1969: 87). The mothers he meets boast of the sweets all the way from America that Rafferty gives their bashful children. The fathers "wanted to talk about skyscrapers and Red Indians, and were disappointed that the only Indians he knew of lived in tarpaper shacks and came peaceably to town in jalopies". The stereotypes multiply, while neither Irish natives nor American transplant can fully understand the truly indigenous, who appear to a casual conversationalist simply curios.

Thatch collapses; iron replaces a roof. Stirabout feeds the family and the pigs. The vagueness of the directions, the townland names, the indirect exchange of pleasantries that lead to no fixed contract, the stagnant economy, and the dismal landscape all depress Rafferty. He must affirm Yankee integrity. As he tells Alice: "They'll kill you in the end. Smile and take a tea break and let you die inch by inch" (1969: 154).

He manages, finally, to secure ten weavers from Leinster, and exults at "putting the Industrial Revolution back in its box," but Alice chides his romanticism. Rafferty admits that weaving will allow the families to buy radios and appliances, and will bring them a few consumer comforts. He must correct himself. Well, he rationalizes, "we're using it, not letting it use us" (1969: 149). He agrees with Frank "that the worker must be taken out of the factory" (1969: 248). The siblings' means to this end reveal their differences. Frank wants to replace union weavers with machines. Pat wants to enable workers to weave at home, back to the cottage industry that preceded the era of steam mills and nylon tweeds. The tweed itself represents for Pat a recovery of the native values lost in the city and the century. When he learns his way around the hills, he notes the passing of heather blooms into red bracken. "Close up it might have been only a sparse tangle of bedsprings rusting in a dump. But on those high little roads he could look ahead and see the hills crowding behind each other, the rounded nubbins of ancient mountains, all in the color of the orange tweed worn by a certain kind of old men and women, a scene to start amateurs on watercolors, and stop professionals with its vulgar perfection" (1969: 97).

An Irish sense of place enters rarely into most of this novel - set within suburban Dublin more often than rural Wicklow. Wahl shuts away Alice, and distracts Rafferty from sightseeing. Both protagonists spend most of their time indoors, and the weather discourages their wandering out. While Rafferty works in the city in a decrepit carriage mews where he supervises the looms and handful of weavers who comprise the Irish branch of the family enterprise, Alice spends nearly all of the novel at home, or climbing the steep hill that affords their run-down Georgian home, Prisma, a slice of slope where Rafferty searched for pig farmers, as seen on the other side of the summit from a moldy bathroom, or sea strip glimpsed from an upstairs window.

Beset by a domestic comedy of errors - a popular genre for the 1960s where a plucky housewife faces menial if genial disasters Alice cannot raise her two daughters, Stella and Vanessa, alone. Rafferty tends to be out. Alice hires a maid, Mary, who appears to have a sinister connection with an old man in the same orange tweed Pat Rafferty admires. Johnnie O'Connor has been sent to look after the family by an I.R.A.-backing, green beer, "Galway Bay" singing, pikes of " 98 caricature, Pat O'Reilley, who sends funds from his home in Oakley that he supposes spark The Cause. Rafferty, only vaguely aware of his own Irish roots in Cork, despises O'Reilley. Prevented only by the fear of the I.R.A. taint coming to the attention of Steichen, who knows Pat 
O'Reilley, Pat Rafferty stays pat if silently furious.

The underground supply of funds for guns turns out to be a cover story invented so O'Connor can inherit O'Reilley's beneficent contribution. O'Reilley, an American benefactor, wishes to uphold for the current generation "the reputation for chivalry" attributed sarcastically to him by Alice when she sends O'Reilley news of a deadly I.R.A. explosion that kills the wife and child of a BSpecial. O'Connor succeeds an earlier Irish recipient who manipulated O'Reilley's naivete. Personal charity has been directly delivered by post to O'Connor, as if to a needy old man. While Alice and Rafferty suspect the whole arrangement has been manipulated for the benefit of a few locals who exploit the misguided jingoism of a deluded Yank, the truth of the arrangement, like those in the I.R.A. itself, remains obscure to outsiders. While Alice and Rafferty trust O'Connor's lack of involvement, they nevertheless remain frightened about blowback.

This meandering subplot, a storyline not included in the novel's central plot as elaborated from the Kenyon Review piece, shows Wahl's own mordant view of Irish American zeal. Of German descent herself, Betty's identification however blurred into Mama or Alice with Jim's distant motherland as embraced by Daddy or Rafferty appears occluded. Instead, a muted tone typifies her renditions of Irish airs by its natives or those once-or-twice removed back in the Upper Midwest, or a family relocated to south Co. Dublin. Despite plot complications which weigh down what began as a more light hearted jibe at Irish lassitude and American attitude, Wahl darkens her tale for a moral purpose, similar to her husband's satire.

At the time of the novel, the I.R.A. remained underground, an outlawed and diminished faction whose actions were few and limited to a witless attack or two on a border outpost. The fact that such an attack kills a B-Special wife and child sharpens Wahl's moral. The patriotic impact desired by meddling Americans sending such aid as solicited by O'Reilley poses a threat to the stability of families and of peace, more than the economics of the incompletely free Irish state.

This shaggy-dog story endangers the reputation of the Raffertys. Alice - by a third- hand relating from Frank of gossip back at Oakley - is implicated by the Cause and its network as a witless Irish American. As Frank reports O'Reilley's ramblings: “Al passed herself off as a loyal Irishman" (1969: 270). O'Reilley blames her fanaticism for the breakup of his support for the I.R.A. The loss of ammunition results in an arms cache being dumped. This predicament forces, by way of O'Reilley's story to save face, O'Connor's expulsion from the rebels. O'Reilley, as he explains to Steichen at a dinner party, loses contact with his secret I.R.A. contact in Dublin. The funds cannot be sent. O'Connor, judged innocent by Alice and Rafferty, becomes the groundskeeper at Prisma, and his income is assured by their labor rather than O'Reilley's misdirected largesse. By now, as this summary may indicate, the novel's subplot turns murky.

The I.R.A. tale grows far-fetched. Wahl does not resolve who can be trusted, or if Pat O'Reilley invents his side of the story to disguise charity or connivance. This stretches the shadow of his character, the threat that lurks even during the relative postwar calm. Death and destruction menace, whether by a mislaid bag of powder left by the gas man working in the lane outside Prisma, or by that same bag dumped in the harbor during a surreal night cruise forced by Rafferty on the ultimately innocent O'Connor. The folly of Pat O'Reilley, whether imagined or real, subterfuge or deliberate, can neither be masked nor denied. This novel, despite its promotion as an affable Irish yarn, turns grim. Rafferty's support from Steichen weakens; his return to Oakley may not transpire. Alice is framed, unwittingly or not, by O'Reilley, and Rafferty comes under suspicion.

Detachment deepens. Wahl's indirect narrative voice alternates between Rafferty and Alice; they (and their creators) favor reserve. As with Daddy's relationships in "Tinkers", any intimacy in this novel between children and parents, or husband and wife, remains almost tacit. Stella and Vanessa suggest in their names Swiftian satire: here children merit names, unlike Powers' story. Yet, children stay mostly at a distance as parents (in real life as well as on the page, given their frequent "removals") face expatriate predicaments. Both families as portrayed by the Powers pair reside during some of the action of "Tinkers" and Rafferty \& Co. in a Georgian monstrosity. Upheavals 
continue; neither head of the household, male nor female, will easily be reconciled to County Dublin. Yet, both the unnamed "Tinkers" clan and the Rafferty family will settle there.

Wahl shares with Powers a tendency that veers away from articulated sentiment to social satire. Jim and Betty refused to let Ireland push them away for long. Rafferty with Alice and Mommy with Daddy refuse to leave Ireland, their adopted home, for good. Both writers through internal monologue and chiseled dialogue convey their characterizations of stubborn, principled strivers.

Alice, in a rare candid moment, turns despondent amidst Prisma's clutter. She resents Rafferty's long lunches and trips on the road. Desperate to keep up production, Pat drags into their drawing room a disused loom and teaches himself in a one-man revival of the family industry. Furthermore, he will not stop weaving. Contrary to his promises, the trade has not become secondary to their enjoyment of the countryside. They never travel. She feels "as if the price of the trip to Ireland were to see nothing of Ireland" (1969: 204).Wicklow, the other side of the hills she climbs with the family's groceries in tow, remains as far away as America.

Alice tries to convince herself that Prisma will be her home. But, like Mama and Daddy in "Tinkers", and like Powers and Wahl, a story of uprooted and demolished houses precedes her. She wonders if she can endure "fog and bog", exile without birch trees, maple sap, or even the sight of wooden houses - let alone seasons.

The rest of the novel expands the action of "A Shorter History of the Irish People". There, Rafferty, in that initial dialogue on the ship coming in to Cobh about his purpose in coming to Ireland cited earlier, admits that he is not, as the Irishman in the story assumes too hastily, "a writer" (Wahl 1964: 306). Neither does he work for the "Embassy". "'No, I'm in tweeds,' Rafferty said, 'though I'd like to do a short history of the Irish people some day"'. Wahl leaves this admission out of her novel. One wonders throughout Betty's presentation of fictionalized versions of herself and her family how much she left out of her own ambitions, as she sublimated these to Jim's own pursuit - in Minnesota and in Ireland, back and forth - of his painstaking craft.

Certainly, Wahl's narrative arc strengthen the unsteady rise and inexorable fall of Rafferty the weaver during his Irish stay. Rafferty symbolizes the inefficiency and the energy combined in the Irish personality, in Wahl's jaundiced view. Alice diminishes the value her husband places on the weaving enterprise. His wish to return to Oakley fades. He imagines himself as one man furthering the Irish trade. When an unseasonably warm summer causes the weavers to attend more to farms than threads, Rafferty may boast: "There was no hope for the world again until men were again choosing to live where their grandfathers lived" (1969: 223). But, Rafferty himself cannot continue in the family craft that four generations back in Oakley had established.

In the story and the novel, Frank's firm, beset by labor disputes with a union, goes bankrupt. He closes the Oakley factory, which attempts to recover its losses by selling the mill "to the town's new seatbelt company"(1964: 316). Automation, in the form of a still infrequent conveyance for many Irish men and women in the novel, the automobile, ends the century of Raffertys employed by the mills of Oakley.

For Rafferty, he finds work for his weavers who are sub-contracted out to a firm that he disposes of the carriage mews to, in return for living as a permanent resident of Prisma. He transforms into a nearly destitute, but securely landed, gentleman scholar. He takes the tail end of a 999-year "Strongbow lease" that dates back to 1175 . The home occupied the ground that became the Pale of Settlement, the Norman fortress that began the conquest of the Irish interior. As their income dwindles, these now permanent Dubliners retreat into their own palisade. With an aptly or ironically named O'Connor at their gate, the newest transplants to Ireland wonder how they will survive. Alice turns to the staples of the native diet: sugar, starch, and tea. The invaders, again, become more Hibernian than the Gaels. The Industrial Revolution that Frank succumbs to proves more reliable than the Irish rebellions that the I.R.A. botches. As a history professor, soon to be prematurely retired by his mid-career shift, Rafferty learns about capitalism the hard way - if from the lessons of the present more than the past.

The story closes with Rafferty facing a long winter night. He resumes his weaving, as the last of his family, the first in many generations 
back in Ireland. His gait has grown clumsy. Newspapers have been stuffed into his slippers. Prisma never warms up. It is winter again, as in "Tinkers". This time, room not at the inn (The Imperial, another Georgian ramble) has been secured, but Rafferty resides but one step ahead of raising the pig in the parlor. Perhaps only his Ballydoo residence separates him from his rural Wicklow counterparts who responded to the bacon questionnaire five years earlier?

Turf fires must be burnt no matter how warm the summer that destroyed the Irish branch of Rafferty's Weavers. Rooms of the house fill with detritus. A loom clatters and shuts off normal conversation with Alice. We hear little from Stella or Vanessa. We see, perhaps, Daddy or Rafferty or Powers from the perspective of Mama or Alice or Wahl. Devotion to a craft, writing or weaving, that demands patience, isolation, and rewards dogged effort. It also, in Rafferty \& Co., closes off the title character from his family, his academic future, and his wife. While this final paragraph in the novel presents Rafferty, we see his actions through the gaze of Alice.

"He would weave until it was dark, and then he would close the shutters and keep on weaving under the ceiling light. Sometimes he would start again after dinner, weaving into the night. And when he had finished a length of tweed, he signed it and fixed to it one of his employer's printed labels: '. . . your Irish tweed, hand woven by native craftsman in their cabins by the turf fires. Go caithidh tú for caithidhtú é, Do fhiodóir, Pádraig Ó Raifeartaigh"” (1969: 293). The label, with its wish that the wearer find long life in the garment by "your weaver" Pat Rafferty, wraps up its own contradictions. The last loom in Leinster, as Rafferty vows, will not rest idle. If Prisma needs heat, he will burn turf. Not a cabin, but nonetheless in this ramshackle County Dublin house near Dún Laoghaire Pat promises to continue his trade, the second oldest ever, as his history teacher once told him.

The Irish language is never mentioned in this novel otherwise, but its fictional revival provides the sentimental message from a stereotypical era when, as Rafferty would approve, the human touch could be felt within the garment made. This connection, severed now by the industrial separation of weaver from buyer and mediated by Pat's faceless anonymous employer, persists by Rafferty's refusal to leave his loom. He may not know who will wear his garment of his beloved orange or green tweed, but the tourist or native, German youth or tinker with a plaid blanket on a Dublin street, for that matter, may find - in Rafferty's romanticism - a dignity that rescues the sight that this Midwestern professor has reduced himself to, pipe clenched and skin and bone. This figure might appear the same in the eyes of Mama, Wahl, or Alice.

Cut off from connections with his ancestors, Pat knows even less than Daddy guesses about his tinker forebears. Alice, while branded an "Irishman" by O'Reilley in contempt or calumny, never reveals in the narrative any of her own ethnic ties to the island. Neither Mama nor Wahl, for that matter, characterize themselves as Irish American, even by marriage. Outside of her fictional characters and their presentation of predicaments similar to those of herself and her own family, one wonders how Betty Wahl regarded her own agreement to put first her long marriage and her commitment to raising five children in Minnesota and Ireland, given the effects on her career.

Powers, by contrast, sides more with his paternal (rather than German maternal) parentage. The strand that weaves back from Irish American to Irish culture in his fiction remains vivid, if one green - or faintly orange - hue among many on his narrative hillsides. For Rafferty and Daddy, the atavistic pull impels them - in subtle and frustrating gestures that mirror the restlessness and reticence of their creator - to grasp an elusive Irish spirit. These returning Yanks perpetuate a heritage of tinkers and weavers in spite of their American, can-do, rational, Midwest selves.

\section{Works Cited}

Casey, Daniel J., and Robert E. Rhodes, eds. 1989. Modern Irish-American Fiction: A Reader. Syracuse: Syracuse UP.

Donoghue, Denis, intro. 2001. The Stories of J. F. Powers. New York: New York Review P. 
Hassler, Jon. 2001. “J. F. Powers and Betty Wahl”. Good People - From an Author's Life. Chicago: Loyola P. 85-106.

Laurance, Anne. 2001. "Resurrecting Powers". Letter to the Editor. Commonweal 128:20. 23 November. http://findarticles.com/p/articles/mi_m1252/is_20_128/ai_80787155 [retrieved 23/6/2007]

O’Connor, Frank. 1956. "Reflections of a petty world”. The Saturday Review. 24 March. 22.

Pierce, David, ed. 2000. Irish Writing in the Twentieth Century: A Reader. Cork: U. of Cork P.

Powers, J[ames]. F[arl].1975. Look How the Fish Live. New York: Doubleday.

1962. Morte d'Urban. New York: Doubleday.

1956. The Presence of Grace. New York: Doubleday.

1947. The Prince of Darkness and Other Stories. New York: Doubleday.

1988. Wheat That Springeth Green. New York: Doubleday.

Powers, Katharine Anne. 2002. "'Suitable Accommodations': a selection of J.F. Powers's letters from Ireland, 1951-63”. Eire-Ireland 37:1/2. Spring/Summer. 93-107.

Wahl, Betty. 1964. "A Shorter History of the Irish People”. Kenyon Review 26. 305-316.

1969. Rafferty \& Co. New York: Farrar, Straus \& Giroux.

Received $28^{\text {th }}$ November $2012 \quad$ Last version $13^{\text {th }}$ February 2013

John L. Murphy coordinates the Humanities sequence at DeVry University in Long Beach, California. His Ph.D. is from UCLA in medieval English literature. Irish language reception by English-language culture, Irish republicanism, Beckett's purgatorial concepts, Jews in medieval Ireland, the reception of Buddhism by Irish intellectuals, folk-rock in Irish counterculture, and the presentation of otherworldly, liminal states in medieval and modern literature illustrate his published research. He reviews books and music over a broad range of topics in print and online, and he contributes to Pop Matters and the New York Journal of Books regularly. 